\title{
The 2001 World Trade Center Disaster: Summary and Evaluation of Experiences
}

\author{
John P. Pryor ${ }^{1, \dagger}$
}

\begin{abstract}
Objectives: To collect and analyze data from deaths and injuries, and from evaluation of the responses by medical services and by fire, rescue, and police services 1 year after the terror attack on World Trade Center. Methodology: Epidemiologic data were collected from all involved agencies and analyzed. The authors personal experience from working at the scene during the event and several other personal testimonies were also included in this analysis.

Results: Totally 2,762 death certificates were issued by the state of New York for victims of the terror attack. 1,361 (49.9\%) of these were issued for victims whose remains could not be identified. All but nine of these victims died at the day of the attack. $77 \%$ of the victims were male, medium age 39 years. Of the dead were 342 fire fighters and paramedics and 60 police officers. A total of 1,103 patients were treated during the first 48 days in five key hospitals receiving the majority of the injured. $29 \%$ of these were rescue workers. $66 \%$ of the injured were male, average age 39 years. The most common injuries were respiratory impairment (49\%) and ocular affection (26\%), many severe. The most common trauma was lacerations $(14 \%)$ and sprains (14\%). Of those administered to hospital, $19 \%$ had trauma and $19 \%$ burns. Head injuries were registered in $6 \%$ and crush injuries in $4 \%$. With regard to response from involved agencies, communication failure was the most common and difficulties in command operations and scene control were also prevalent.

Conclusions: The difficulties encountered were very similar to those commonly seen in major accidents or disasters, although on a great scale. Response plans have to be critically reviewed based on the experi-
\end{abstract}

\footnotetext{
$1, \dagger$ John P. Pryor was killed during his work in Iraq on Christmas Day 2008. Formerly: Division of Traumatology and Surgical Critical Care, Department of Surgery, University of Pennsylvania School of Medicine, Philadelphia, PA, USA.
}

ences from this and other events, in order to pre-empt difficulties such as those described here in future responses to major urban accidents and disasters.

\section{Key Words \\ Disaster $\cdot$ Triage $\cdot$ Terrorism $\cdot$ World Trade \\ Center · Fires - Disaster planning · Emergency \\ medical services}

Eur J Trauma Emerg Surg 2009;35:212-24

DOI 10.1007/s00068-009-9902-6

\section{Introduction}

On 11 September 2001, two hijacked aircraft were deliberately flown into the twin towers of the World Trade Center in New York City, USA. The disaster represents the second largest loss of life from a single event in the peacetime history of the USA [1]. Many of the classic challenges of disaster response were present during the chaotic hours that followed the twin tower collapse. Of the most prevalent were difficulties in communication, scene control, and command operations. New York City deals with major disasters on a monthly basis, and the city has one of the most advanced infrastructures in the world for responding to events such as these. In spite of this, 403 rescue workers were killed when the worse case scenario of a complete building collapse occurred. Although it represents the largest and most complex urban disaster in the recent US history, many of the lessons learned from this event are applicable to disasters on all scales.

In the time since 11 September, there has been considerable reflection on the events of that day. The response by fire, emergency medical services (EMS),

Received: September 25, 2002; revision accepted: November 27, 2002 First Published in Int J Disaster Medicine 2003;1:56-68;

Published Online: June 1, 2009 
and police departments has been critically reviewed. Epidemiologic data on the deaths and injuries caused by the attack have been collected by several agencies. In spite of this, there are very few published reviews of the overall disaster response, and specifically, the medical response. This report is an attempt to summarize the events, operations, and outcomes of the 2001 World Trade Center Disaster. In addition to factual data, evidence from testimonials, published accounts, and the author's personal experience have been pooled to form a more complete picture of events that occurred during the first $24 \mathrm{~h}$ of the disaster.

\section{Timeline of Events}

American Airline flight 11, a Boeing 767, struck the North tower of the World Trade Center (WTC) at 8:46 am Eastern Standard Time (EST). Hundreds of civilians witnessed the event, along with several firefighters who were working at another alarm in the area. First arriving fire and EMS units staged just outside the WTC complex. The twin towers are two of the seven buildings that make up the WTC, a complex that occupies approximately four square city blocks (Figure 1). The initial fire incident command post (ICP) was set up in the ground floor lobby of the North tower by the first battalion chief to arrive (Table 1). This command post was eventually staffed by some of the highest-ranking uniform officers of the Fire Department of New York (FDNY). This command post

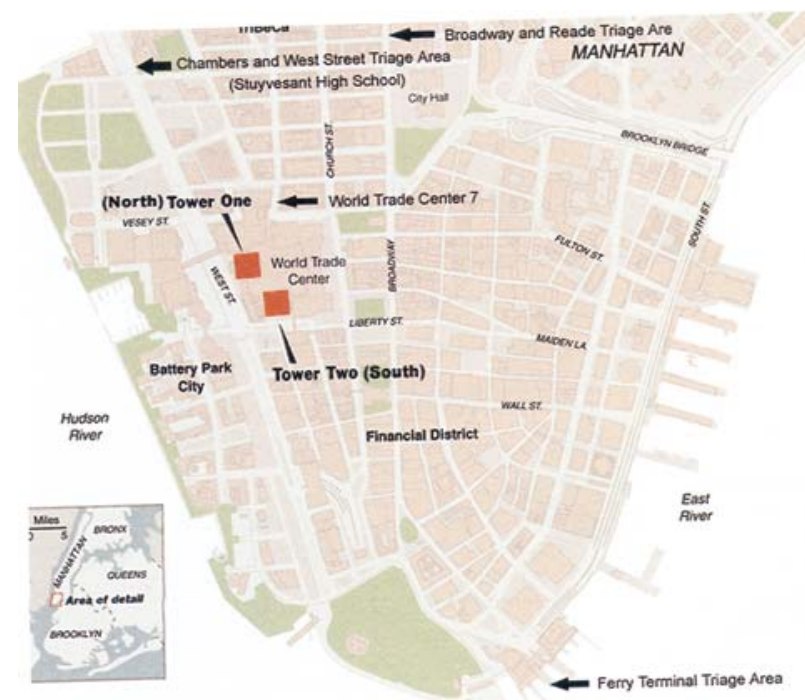

Figure 1. A map of lower Manhattan showing the World Trade Center complex and surrounding area. Major divisions (triage and treatment areas) established by EMS command are labeled.
Table 1. The FNDY command structure.

\begin{tabular}{|c|c|c|}
\hline Fire & EMS & Civilian posts \\
\hline $\begin{array}{l}\text { Chief of the department } \\
\text { Assistant Chief } \\
\text { Battalion Chief } \\
\text { Captain } \\
\text { Lieutenant } \\
\text { Firefighter }\end{array}$ & $\begin{array}{l}\text { Chief of EMS operations } \\
\text { Assistant EMS Chief } \\
\text { Division Chief } \\
\text { EMS Captain } \\
\text { EMS Lieutenant } \\
\text { Paramedic } \\
\text { Emergency Medical } \\
\quad \text { Technician (EMT) }\end{array}$ & $\begin{array}{l}\text { Fire Commissioner } \\
\text { Deputy Commissioner } \\
\text { Chief Medical Officer } \\
\text { Assistant CM0 } \\
\text { Chaplain }\end{array}$ \\
\hline
\end{tabular}

within the lobby of the building allowed easy coordination of the evacuation and the ability to organize teams that would be sent up 78 floors to light the active fire. In addition, the inside location had an unanticipated advantage in that it protected rescuers from falling debris and bodies around the periphery of the building. Victims were falling/jumping at the rate of about one a minute from heights as great as 1,300 feet. Each high-energy impact had the potential for causing serious injury to anyone in the vicinity of the landing zone [2].

At 9:03 EST a second aircraft, United Airlines flight 175, impacted the South tower of the WTC. By this time the plaza surrounding the towers was crowded with hundreds of civilians and rescue workers. Fire officers in the North tower command post heard the noise of the impact but did not immediately know what had happened. Eighteen minutes had elapsed from the time the first plane hit the North tower. Although this may have been adequate time for an evacuation of the upper floors of the South tower, a general overhead announcement was being made for everyone in the South tower to remain in their offices. This was undoubtedly done to control the scene by decreasing the number of civilians evacuating into the plaza. In retrospect, it was a fatal decision since many people who would have evacuated returned to their offices only to be trapped and killed.

Hundreds of firefighters, police officers, Port Authority police officers, and members of several governmental agencies were involved in the initial evacuations. Some of the first medical victims were those burned after ignited jet fuel spilled into the elevator shafts. These victims were on the ground floors when they were burned, which allowed them to evacuate and present early to medical personnel. The vast majority of victims, however, were trapped either in floors above the fires or in the process of evacuating 
down 78-90 flights of stairs. Medical triage was set up outside the tower, away from the danger of falling debris, but still within the WTC complex.

At 9:50 EST (65 min into the disaster) tie South tower, the second building to be struck, completely collapsed. A camera crew that was accompanying officers at the command post in the North tower documented the event [2]. After a tremendous noise and vibration, the lobby filled with thick black smoke to the point where breathing was extremely difficult. The smoke and debris were heavily particulate with large pieces of airborne material that tended to lodge in the upper airways. In addition to many of those in the South tower, some of the FDNY officers at the command center were killed at this point, including the Fire Department Chaplain, Father Mychal Judge. Those who were not killed were barricaded in the building and struggled to find a way out into the street.

The collapse sparked a wider evacuation of lower Manhattan. The smoke and choking debris involved the entire lower tip of Manhattan Island, an area of approximately one-half square mile. The mayor of New York City, Rudolph Giuliani, responded directly to the scene and was temporarily trapped in an adjacent building by falling debris from the first building collapse. After escaping through a basement door, he set a priority of evacuating lower Manhattan and coordinating rescue efforts. Understanding the need for good communication with the citizens of New York, he performed a "walking" news conference while escaping with his advisors out of the disaster site [3]. As they rushed north away from the scene, they instructed the citizens by television and radio how to evacuate and attempted to calm fears of further attacks. These early press briefings were later credited with keeping the city from decompensating into hysteria.

When personnel at the fire ICP realized that the South tower had completely collapsed, a general evacuate order was sent to all firefighter units in the North tower. It is clear from radio recordings and personnel accounts that many firefighters did not receive this order due to communication difficulties. Radio traffic was crowded, and many of the radio repeaters (boosting antennas) were on the top of the South tower that had just collapsed. Cell phone communication was also greatly impeded by circuit overloading. The result was that many firefighters in the North tower never received the evacuation order.

The North tower collapsed at 10:29 am EST, $1 \mathrm{~h}$ and $44 \mathrm{~min}$ from the first plane impact, and $39 \mathrm{~min}$ after the first tower collapse. In this short time, hundreds of crucial decisions were made by thousands of victims, rescue workers, city officials, and others. What occurred next was a monumental rescue effort that over days and weeks transformed into a Herculean task of recovering and identifying the dead.

\section{Statistics \\ Deaths}

Several agencies have collected data on the injured, dead, and missing. These include, among others, the Centers for disease control (CDC), the New York State Department of Health (DOH), and various New York City agencies such as Department of Health and Mental Hygiene (DOHMH). The CDC has published several reports, the latest in September 2002. Total number for those dead and missing has changed frequently as ongoing investigations are completed and as tissue remains are identified. As of August 16, 2002 a total of 2,726 death certificates were issued by the State of New York for victims of the WTC attack (Table 2). The cause of death in most of the cases was physical injuries to the head, chest, etc. [4]. The most common method of identification of remains was DNA analysis (645), dental records (188), and fingerprints (71). In all cases the manner of death is listed as "homicide." Of the 2,726 death certificates issued, 1,361 (49.9\%) were issued for decedents whose remains have not been identified. All but nine victims died on the day of the attack, the last patient expired on 30 October 2001 [5].

The vast majority of victims were males $(77.7 \mathrm{t})$ with a median age of 39 years. Although most victims were American citizens, 27 people from 8 other countries were killed. Death certificates were not issued for the 10 terrorists identified. In addition, there appear to be 93 victims who have not been issued a death certificate either because the family has not requested one or an investigation is pending. If these victims are eventually added the estimated death would become 2,819, not including the terrorists [6].

In addition to the loss of civilian lives, a large number of rescue workers were also killed. The Fire Department of New York reports 343 firefighters and paramedics killed or missing [7]. The Port Authority, a police agency that has jurisdiction over the WTC complex suffered 37 officers killed or missing [8]. In addition, 23 officers of the New York Police Department (NYPD) are dead or missing in the attack [9]. These victims are included in the overall totals given above.

\section{Injured}

Data on the number and type of injuries are less, precise then the fatality information. This is due to 
Table 2. Number of deaths ${ }^{a}$ at the World Trade Center, by racial/ ethnic group, education and sex ${ }^{b}-$ New York City, 11 September 2001.

\begin{tabular}{|c|c|c|c|}
\hline \multirow[t]{2}{*}{ Racial/ethnic group/education } & \multicolumn{2}{|l|}{ Sex } & \multirow[t]{2}{*}{ Total } \\
\hline & Male & Female & \\
\hline \multicolumn{4}{|l|}{ Hispanic } \\
\hline Less than high school & 9 & 2 & 11 \\
\hline High school & 68 & 19 & 87 \\
\hline Some college & 30 & 26 & 56 \\
\hline College or more & 69 & 34 & 103 \\
\hline Unknown & 1 & - & 1 \\
\hline Total & 177 & 81 & 258 \\
\hline \multicolumn{4}{|l|}{ White, non-Hispanic } \\
\hline Less than high school & 5 & 1 & 6 \\
\hline High school & 246 & 100 & 346 \\
\hline Some college & 199 & 36 & 235 \\
\hline College or more & 1,195 & 267 & 1,462 \\
\hline Unknown & 14 & 3 & 17 \\
\hline Total & 1,659 & 407 & 2,066 \\
\hline \multicolumn{4}{|l|}{ Black, non-Hispanic } \\
\hline Less than high school & 3 & - & 3 \\
\hline High school & 44 & 24 & 68 \\
\hline Some college & 21 & 8 & 29 \\
\hline College or more & 65 & 44 & 109 \\
\hline Unknown & 3 & 3 & 6 \\
\hline Total & 136 & 79 & 215 \\
\hline \multicolumn{4}{|l|}{ Asian/Pacific Islander } \\
\hline Less than high school & - & - & - \\
\hline High school & 8 & 2 & 10 \\
\hline Some college & 4 & 3 & 7 \\
\hline College or more & 109 & 47 & 156 \\
\hline Unknown & 1 & 2 & 3 \\
\hline Total & 122 & 54 & 176 \\
\hline \multicolumn{4}{|l|}{ Other and unknown } \\
\hline Less than high school & - & - & - \\
\hline High school & 1 & 1 & 2 \\
\hline Some college & 1 & 1 & 2 \\
\hline College or more & 7 & - & 7 \\
\hline Unknown & - & - & - \\
\hline Total & 9 & 2 & 11 \\
\hline \multicolumn{4}{|l|}{ All racial/ethnic groups } \\
\hline Less than high school & 17 & 3 & 20 \\
\hline High school & 367 & 146 & 513 \\
\hline Some college & 255 & 74 & 329 \\
\hline College or more & 1,445 & 392 & 1,837 \\
\hline Unknown & 19 & 8 & 27 \\
\hline Total & 2,103 & 623 & 2,726 \\
\hline
\end{tabular}

${ }^{a}$ Includes three deaths outside New York City

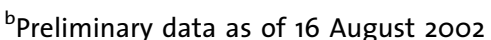

victims being treated by many hospitals across three states and by the fact that many patients received treatment outside of the hospital system. Within $6 \mathrm{~h}$ after the attacks, the New York City DOHMH began to accumulate statistics on the number and type of injury treated at five key hospitals in lower Manhattan. These assessments were begun by the DOHMH personnel despite having to evacuate their own headquarters because of close proximity to the disaster [6]. These five hospitals received most of the patients from the disaster, including the most critical. A total of 1,103 patients injured in the disaster were treated within the first 48 hours at these five hospitals. Of these, 320 $(29 \%)$ were rescue workers who were injured during rescue operations (Table 3). Although the majority of patients received care within $7 \mathrm{~h}$ of the attack, there was a second wave of injured that peaked at $27 \mathrm{~h}$ (Figure 2). Although not certain, this may correlate with readmission of personnel to the scene after a brief period of full evacuation that occurred up until $6 \mathrm{~h}$ after the second collapse. Similar to the data on nonsurvivors, the majority of survivors treated at these hospitals were male (66\%) with an average age of 39 years.

There were two broad categories of complaints that brought victims to seek medical attention, traumatic and medical conditions (Table 4). Traumatic injuries included blunt and penetrating mechanisms from falling debris, falls, burns, and crush injury. The most common complaints among survivors, however, were non-traumatic conditions such as respiratory (49\%) and ocular irritation (26\%). The eye irritation was severe, with enough burning and tearing to virtually incapacitate the ability to function. Breathing was difficult and a constant deep cough developed that was productive of soot-tinged sputum. The most common traumatic injuries were laceration $(14 \%)$ and sprains (14\%). Among those admitted to the hospital, fractures $(19 \%)$ and burns $(19 \%)$ were more common. The most serious injuries were closed head trauma $(6 \%)$ and crush syndrome $(4 \%)$. Only $16 \%$ of all patients treated by these five hospitals were admitted for further care.

\section{Financial Cost}

The disaster had many financial impacts on the city, state, and nation. The local economic loss was not only in property damage and capital expenditures for rescue and clean-up efforts, but also from major losses in City revenue from decreased local business economy and tourism decline. A report by the Federal Reserve Bank of New York estimates a total cost of \$33-36 billion [10]. This figure includes an estimated loss of 42,000-51,000 private sector jobs along with the loss of potential income of those killed in the attacks. It is estimated that 
Table 3. Number and percentage of injuries ${ }^{a}$ to rescue workers and non-rescue survivors reported by five hospitals after the attack on the World Trade Center: by injury - New York City, from 8 am 11 September to 8 am 13 September 2001.

\begin{tabular}{|c|c|c|c|c|c|c|}
\hline \multirow[t]{2}{*}{ Injury } & \multicolumn{2}{|c|}{ Rescue workers $(n=279)$} & \multicolumn{2}{|c|}{$\begin{array}{l}\text { Non-rescuer survivors } \\
(n=511)\end{array}$} & \multicolumn{2}{|c|}{ Total $(n=790)$} \\
\hline & No. ${ }^{b}$ & $(\%)^{c}$ & No. & $(\%)$ & No. & $(\%)$ \\
\hline Inhalation & 118 & $(42)$ & 268 & $(52)$ & 387 & $(49)$ \\
\hline Ocular & 108 & (39) & 96 & $(19)$ & 204 & $(26)$ \\
\hline Sprain or strain & 44 & $(16)$ & 64 & $(13)$ & 110 & $(14)$ \\
\hline Laceration & 23 & $(8)$ & 87 & $(17)$ & 110 & $(14)$ \\
\hline Contusion & 44 & (16) & 54 & (11) & 98 & (12) \\
\hline Fracture & 13 & $(5)$ & 33 & (6) & 46 & (6) \\
\hline Burn & 6 & (2) & 33 & (6) & 39 & (5) \\
\hline Closed head & 3 & (1) & 11 & (2) & 14 & (2) \\
\hline Crush & 3 & (1) & 5 & (1) & 8 & (1) \\
\hline
\end{tabular}

${ }^{\mathrm{a}}$ Excludes unspecified injuries or illnesses

${ }^{b}$ Totals might exceed number of survivors because some survivors might have sustained multiple injuries

${ }^{\mathrm{C}}$ Totals might exceed $100 \%$ because some survivors might have sustained multiple injuries

Figure 2. Number of World Trade Center attack survivors with injuries reported by five hospitals* - by number of hours from the initial attack to medical assessment - New York City, from 8 am 11 September to 8 am 13 September 2001. Adapted from MMWR 2002; 51:1-5 [6].

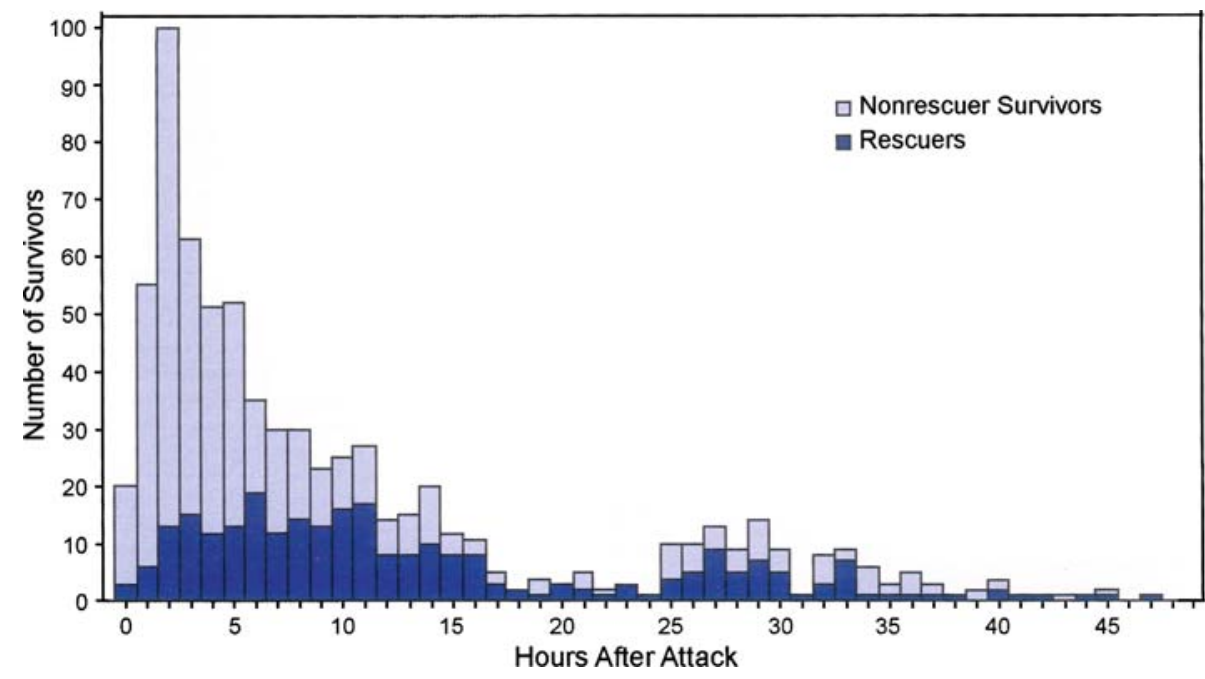

redevelopment of the WTC complex will cost $\$ 11$ billion. Any estimate on the impact nationally would include a large expansion in federal spending for increased security, a military expansion, and a comprehensive military campaign that is still ongoing in the Middle East. These numbers are not yet calculated.

\section{Fire and Rescue Operations}

The initial rescue response began almost immediately after the first aircraft impacted the North tower. The first alarm for fire units in lower Manhattan was quickly elevated to a third alarm by the first arriving battalion chief Joe Pfeifer. Each "alarm" would typically dispatch three engine and two ladder companies, which included approximately 25-30 firefighters aboard five trucks. Eventually a full five alarm (the highest level of response) would be activated. This would officially direct at least 25 trucks with 125-150 firefighters to respond directly to the scene [11]. When the scope of the disaster became apparent with the second aircraft crash, the fire dispatch center-initiated what was once referred to as a "borough call", the highest level of disaster response possible within the city. With the aid of the Starfire vehicle tracking computer system, all available units in Manhattan, a total of 121 engine companies, 62 ladder companies, 4 rescue squads and various other specialty companies were sent to the scene - a force equivalent to 22 alarms [12]. This massive response, almost half of the entire Fire 
Table 4. Number and percentage of injuries ${ }^{a}$ reported by five hospitals after attack on World Trade Center, by injury - New York City, from 8 am 11 September to 8 am 13 September 2001.

\begin{tabular}{|c|c|c|c|c|c|c|c|c|}
\hline \multirow[t]{2}{*}{ Injury } & \multicolumn{2}{|c|}{$\begin{array}{l}\text { Hospitalized } \\
(n=139)^{b}\end{array}$} & \multicolumn{2}{|c|}{$\begin{array}{l}\text { Treated and released } \\
(n=606)\end{array}$} & \multicolumn{2}{|c|}{$\begin{array}{l}\text { Undocumented } \\
\text { follow-up care } \\
(n=45)\end{array}$} & \multicolumn{2}{|c|}{ Total $(n=790)$} \\
\hline & No. ${ }^{c}$ & $(\%)^{d}$ & No. & $(\%)$ & No. & $(\%)$ & No. & $(\%)$ \\
\hline Inhalation & 52 & (37) & 300 & $(50)$ & 34 & (76) & 386 & (49) \\
\hline Ocular & 10 & (7) & 185 & (31) & 9 & (20) & 204 & (26) \\
\hline Laceration & 25 & (18) & 80 & (13) & 5 & (11) & 110 & (14) \\
\hline Sprain or strain & 17 & (12) & 85 & (14) & 6 & (13) & 108 & (14) \\
\hline Conclusion & 29 & (21) & 66 & (11) & 3 & $(7)$ & 98 & (12) \\
\hline Fracture & 27 & (19) & 19 & (3) & 0 & $(0)$ & 46 & (6) \\
\hline Bum & 27 & (19) & 12 & (2) & 0 & (0) & 39 & (5) \\
\hline Closed head & 8 & (6) & 6 & (1) & 0 & $(0)$ & 14 & (2) \\
\hline Crush & 6 & (4) & 2 & $(0.3)$ & 0 & (0) & 8 & (1) \\
\hline
\end{tabular}

${ }^{\mathrm{a} E x c l u d e s}$ unspecified injuries or illnesses

bIncludes two survivors who died during emergency care

'Totals might exceed total number of survivors because some survivors might have sustained multiple injuries

${ }^{\mathrm{d}}$ Totals might exceed $100 \%$ because some survivors might have sustained multiple injuries

Department of New York, was made without the usual authorization from a high-level FDNY officer. Dispatcher John Lightsey lamented, "Here in Manhattan we dispatched everyone, every company, from 125 th street on down... [concerning the lack of authorization] We didn't follow the rules; we went above the rules" [13]. By 9:00 am, 15 min after the first impact, Commissioner Van Essen estimated that 200 firefighters were already in the tower lobbies [14].

In addition to the units that were officially dispatched, many fire and police personnel autonomously responded directly to the scene. This included personnel from virtually every agency and from every rank from probationary firefighter to Mayor of the city. Commissioner Van Essen recalls, "With the second attack, even more units were flooding the scene, many going up [the stairwells to the fire],... some heading inside without checking in at the command post" [15]. Assistant Chief of the Department Harry Meyers recalled, "There was a mutual aid call for Westchester and Nassau counties [neighboring municipalities]. The original plan was for them to come in and man our outlying firehouses near the city lines, which would free our firefighters to come to the operation... [instead] they came to the scene, and no one seemed to be in charge of this" [16]. The streets around the WTC complex soon became jammed with vehicles from every agency in the city.

The first priority was evacuation of the towers. On a typical workday, each 110 -storey building bolds
25,000 workers and up to 25,000 visitors [17]. Thus during the height of the evacuation, approximately $90,000-110,000$ persons needed to be guided from the towers. The evacuation operation was severely hampered by technical complications. Deputy Chief Pete Hayden reported, "...All the building services were out. The elevators were not working; there were no communication lines established. Basically, we had no communication at all. No elevator controls, no cell lines, no landlines. We were really at a distinct disadvantage" [18]. In addition to evacuation, fire control was an early priority. Initial waves of firefighters were dispatched to the floors with active fires. Since the elevators were not an option, this entailed a 70-storey climb with full gear. After review of radio communications, it is clear that many firefighters did indeed reach the active fire and were conducting rescue operations when the collapse occurred.

Evacuation from floors at or above the fires was impossible. The structure of the towers was such that all of the fire stairwells and elevators were contained within the central core of the tower. The path of impact for both aircraft included the core of the building making almost every stairwell impassable. There are only four known survivors who were originally above the level of impact when the aircraft crashed. All four used the only known passable exit, staircase A in the South tower [19].

It is remarkable that each tower initially withstood the impact of a large commercial aircraft without an 
immediate collapse. The buildings' engineers had designed the towers with the possibility of an aircraft collision in mind. What was not as well appreciated was the contribution of the subsequent fire on the superstructure. The towers contained a vast number of offices, each with a significant amount of combustible material such as furniture and paper products that fueled a massive fire. Experts agree that the fireproofing on the steel of the building was damaged with the impact, decreasing the ability of the structure to withstand heat. In addition, the fire suppression (sprinkler) system was incapacitated when the main water pipes running in the core of the building were severed by the impact. Without the fireproofing and a functional suppression system, fires became uncontrolled, reaching temperatures of $2,000^{\circ} \mathrm{F}$ [20]. These excessive temperatures ultimately led to the collapse of each tower, although by slightly different mechanisms [21].

After the collapse surface fires were spread over the entire collapse zone. Other smaller buildings in the complex, including the 44-storey WTC building number 7 (WTC7), was severely damaged and now fully involved in fire. Assistant Chief Harry Meyers remembers, "We couldn't fight the fire in [WTC7] because we didn't have enough water. All the water mains were down. What water we did have was being supplied by the boats [in New York Harbor] through large diameter hose" [22]. By this time there was a general evacuation order for all personnel in lower Manhattan. Many fire and police units pulled back to Chambers Street and West Side Drive to stage and regroup (Figure 1) This re-organization continued until late afternoon. Commissioner Van Essen recalls, "Around 5:30 pm, just as the sun started to drop below the horizon, [WTC7] finally crashed to the earth. The destruction of a 44-storey building was now only the third-worst collapse in recent memory, and a mere footnote to the disaster... Once the dust cleared, the chiefs, allowed hundreds of impatient firefighters gathered North of the site to go the pile" [23].

Priorities were to suppress surface fires and to begin a search and rescue operation. Both were complicated by difficulty in walking on the debris pile and by the arrival of nightfall. The debris pile was several storeys high in some places and consisted of a twisted mass of sharp steel and burning debris, separated by smoke-covered pits as deep as 50 feet or more (Figure 3). In spite of the ongoing danger of unstable rubble, heavy smoke, ongoing fires, and the risk of natural gas explosions, an active rescue effort continued throughout the first night. Unfortunately, only five survivors were pulled from the rubble in the next $24 \mathrm{~h}$,

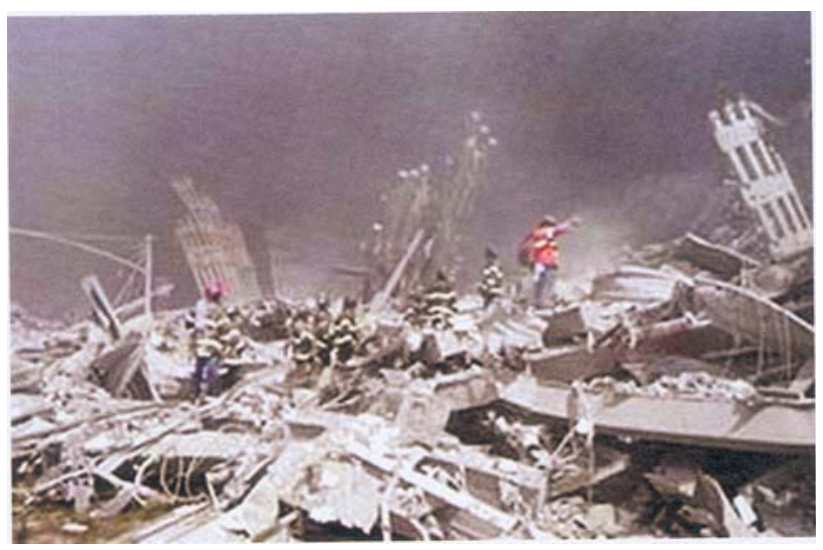

Figure 3. A representative photograph of the rubble pile at the epicenter of the collapse zone, also known as 'ground zero.' Note the hazards of sharp debris, open pits, active fires, and heavy smoke conditions.

all trapped rescue workers. No one else was found alive and there is no evidence that anyone survived the initial collapse and expired afterwards. Remarkably, there were no additional deaths of rescue workers for the duration of the search and rescue Operation, or during the recovery effort that would take place over the next several months.

\section{The Medical Response \\ EMS Command}

Three well-demarcated waves of injuries were observed during the disaster. The impact of the aircraft into the towers undoubtedly caused hundreds of casualties and injuries. The vast majority of injured survivors in this first wave were not able to evacuate the buildings and perished in the collapse without receiving medical attention. This tir.st wave also included a few patients that were burned when ignited jet fuel filled elevator shafts and engulfed the occupants. As discussed, these patients were on the ground floor and were able to escape and present early to paramedics. Along with the burn victims, many people outside the building were hit by falling debris. Most of these patients were rapidly transported by ambulance to hospitals north of the disaster scene. Those patients that escaped to the south of the scene were evacuated by way of barges from the Ferry Terminal at Battery Park, across the Hudson River to New Jersey. Here, emergency medical personnel set up triage areas and transported patients to various nearby hospitals. Any remaining patients in the first wave that had not escaped the building or the immediate area when the collapse occurred were most likely killed. 
The collapse caused a second wave of injuries to civilians and rescue workers around the periphery of the collapse zone. Evacuation of these patients was similar to the first wave except that it occurred in a more chaotic fashion since personnel were in disarray after the collapse. Lastly, those injured in the subsequent rescue effort represented a third wave of injuries that continued at a low rate for several months.

EMS command was first established by Car 42 (EMS officer) just outside the North tower and staging areas were established around the WTC complex. Almost immediately communication difficulties were encountered due to extensive radio traffic on the common EMS radio frequency [24]. By 9:00 am EST, a total of 36 ambulances had arrived and were staging outside the towers. These units began the triage, treatment, and transport of the first wave of injured. The majority of these units, along with the EMS command post, were subsequently destroyed in the first tower collapse.

Communications that were marginal to begin with became even worse after the tower collapse. Radio repeaters (booster antennas) that were situated on the roof of the tower were destroyed, inactivating local communication on the EMS frequency. For up to an hour after the second collapse, there was no effectual communication between EMS command, dispatch, and responding units [25]. EMS command was eventually re-organized, along with fire and police services, several blocks from the collapse zone at Chambers Street. At approximately 11:00 am EST, official EMS staging areas were designated at the Chelsea Pier, the Staten Island Ferry Terminal, Broadway at Reade Street, and at Stuyvesant High School located on Chambers Street (Figure 1). At this point an additional 97 ambulances and 22 EMS supervisors were responding to the scene [26]. Operations at the Stuyvesant staging area are discussed later.

The first critical patients were the severely burned victims mentioned previously. Many of them were taken to St Vincent's Hospital, approximately 20 blocks from the scene [26]. Being situated in the middle of Manhattan, St. Vincent's hospital was a veteran of disasters and had a very well-designed disaster plan. The weather that day was warm and sunny, allowing the majority of triage activities to be performed outside the emergency room. Critical patients were taken into the emergency room, while those less injured were treated outside. Personnel were pooled into ready rooms, one for surgeons, physicians, nurses, etc. When a particular talent was needed, supervisors in these ready rooms were contacted. Social workers and dis- charge planners went to the wards and triaged people for emergency, in some instances physically helping them into waiting taxicabs. Each patient was formally admitted with pre-designated disaster registration kits that had unique medical record numbers for each of the several hundred patients treated that day. Areas were pre-designated as emergency room spill-over treatment rooms, such as the gastroenterology suite and the physical therapy gym. All personnel, from housekeeping to senior administration, had an assigned role in the overall disaster plan and had executed it flawlessly.

Assuredly, the same types of preparations were being completed in hospitals throughout the city, albeit some to a less accomplished degree. Hospitals throughout the northeast United States also prepared for a possibility of patients being transferred as part of a national disaster plan. Hospitals throughout the city began to deal with very similar problems. Rick Nierenberg, director of the New Jersey Medical Center emergency department wrote of their experience treating 150 patients from the disaster, "The separation of "walking wounded" from critically ill and injured patients were accomplished by a remarkable effort to set up separate, but contiguous facilities. Our auditorium was set up to serve as an expanded "fast track", where our minor cases were sent from triage." This effectually reserved needed resources in the emergency room proper for more critically injured [28].

Another hospital that received a great many patients was Bellevue Hospital Center-downtown. Dr. Stephen Menlove, chair of the disaster committee reflected, "During the first $24 \mathrm{~h}$ of the disaster we treated approximately 186 patients from the site. There was one death, 10 patients required surgical intervention, 25 patients were admitted, and 150 patients were treated and released... One of our problems was crowd control as so many of our medical professionals gravitated to the emergency department to observe and offer their services" [29]. Dr. Kevin Chason of Mount Sinai Hospital highlighted two recurring problems in hospital response to disasters, "... There was communication breakdown between the city's disaster operations and the hospitals, so we were in the dark as to what was coming our way... Our phone system was unreliable and using radios at key posts was very helpful... Because of the lack of communication, we were also uncertain of the decontamination and containment needs of our patients" [29].

As with many other major disasters of this century, over-triage was a significant problem and hospitals quickly became over-run with minor injury patients 
[30]. This occurs when too many patients with minor injuries are given a high triage priority and sent to hospitals. Andrea Scheibner of Beth Israel Medical Center commented, "As victims arrived, things got chaotic. The [emergency department] filled up rapidly. Triage was moved outside the hospital... stable patients were sent to makeshift areas of the hospital so that we could reserve the [emergency department] for the most critical patients" [31]. Over-triage can cause hospital emergency departments to be over-run with minimally injured patients, consuming resources and potentially delaying care to more severely injured patients. Frykberg reported an over-triage rate of $80 \%$ among the 346 patients treated during the Beirut Airport terrorist bombing in 1993. This may have contributed to a delay in the treatment, and a relatively high mortality $(37 \%)$ of the relatively few $(n=19$, $\mathrm{U} \%$ ) critical patients [32].

Over-triage was also noted during the management of 111 patients from the Atlanta Olympic Park bombing in 1996, but was not felt to affect overall patient morbidity [33]. One measure of over-triage is the eventual admission rate of patients to the hospital. Recall that of the estimated 1,103 survivors who were treated at five hospitals, only $181(16 \%)$ were injured severely enough to be hospitalized. This is similar to other recent disasters, such as the Oklahoma City bombing where only $83(11 \%)$ of the 759 survivors were injured severely enough to be hospitalized [34].

\section{Field Hospitals}

After the initial impact and then again after the tower collapse, EMS and fire rescue units established triage aid staging areas throughout the city. These areas changed several times as the disaster expanded. The first staging areas directly outside the WTC towers were all completely destroyed in the collapse (Figure 4). Two FDNY paramedics were among the rescue workers killed that day.

After the second building collapse, and re-organization by EMS command, several divisions (designated treatment staging areas) were established at different locations approximately a quarter of a mile from the collapse zone [25]. A description of one representative field hospital is provided from the author's personal experience. Immediately after the collapse, all rescue personnel were evacuated from the collapse zone, which included the entire southern tip of Manhattan Island. The fire and police departments set up a command center at the corner of Chambers Street and West Side Drive. A medical triage area was also set up at this location. At approximately 11:30 am EST, $1 \mathrm{~h}$

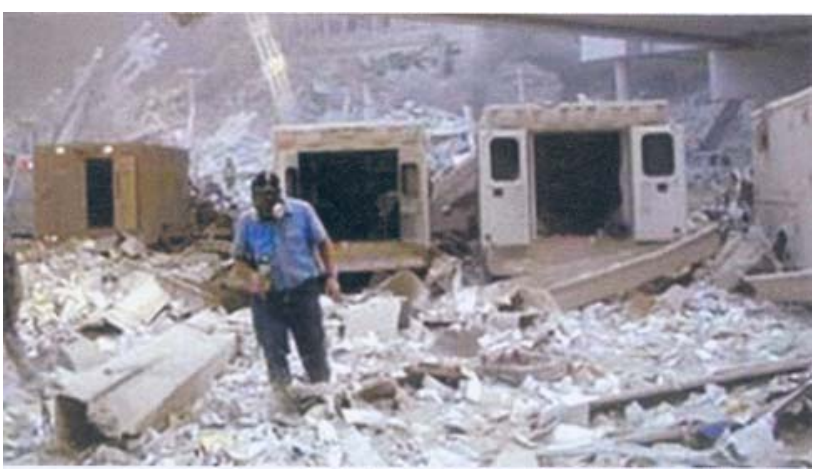

Figure 4. A row of ambulances that was originally situated to receive casualties just outside the tower buildings. The vehicles were destroyed by the collapse of the towers.

after the second tower collapse, this triage area was staffed with approximately 30 emergency medical technicians (EMTs) and paramedics, one anesthesiologist, four medical physicians, one trauma surgeon (author), three nurses, and several medical students. All of the non-EMS personnel were volunteers and not part of the official response. Patients evacuating north zone were evaluated on arrival to from the collapse formally triaged using the red, yellow, green, black designation (Table 5). Critical Patients (red) were stabilized and immediately transported by one of the awaiting ambulances. Those with less serious injuries (yellow and green) were evaluated by practitioners and treated. Similar to the hospitals, the area soon became filled with patients who had minor injuries. The Stuyvesant High School, which was situated on the corner of Chambers Street, was commandeered to provide a treatment area for minor injuries. As the day progressed, approximately 150-200 patients were treated in the lobby of the high school. The majority of injuries included eye irritation, respiratory difficulties, minor lacerations, and soft tissue injuries (possible fractures). Several eye irrigation stations were set up and staffed by the ever-increasing number of volunteers who started to flood the school. Although approximately 30-50 patients were transported by ambulance to hospitals, the vast majority of patients treated here were released without transport to a hospital. Initially no medical records were kept on those who were

Table 5. The New York State EMS triage system. 
treated and released. After several hours of operation, EMS supervisors began to register basic information on patients being treated at the center. By 5:00 pm EST the number of medical volunteers vastly outnumbered patients at the center and the Stuyvesant area was dismantled.

Scene control at this field hospital was difficult on all levels, from patient and volunteer control to vehicle flow. Fire apparatus and ambulances from NYC, Long Island, Westchester County, and New Jersey responded from all directions into Chambers Street, to a point where there was complete gridlock of vehicles. West Side Drive, one of the largest and widest streets in the city, provided direct access, into and out of the collapse area (later known as "ground zero") (Figure 5). However, by several hours after the collapse, the highway became completely filled with fire

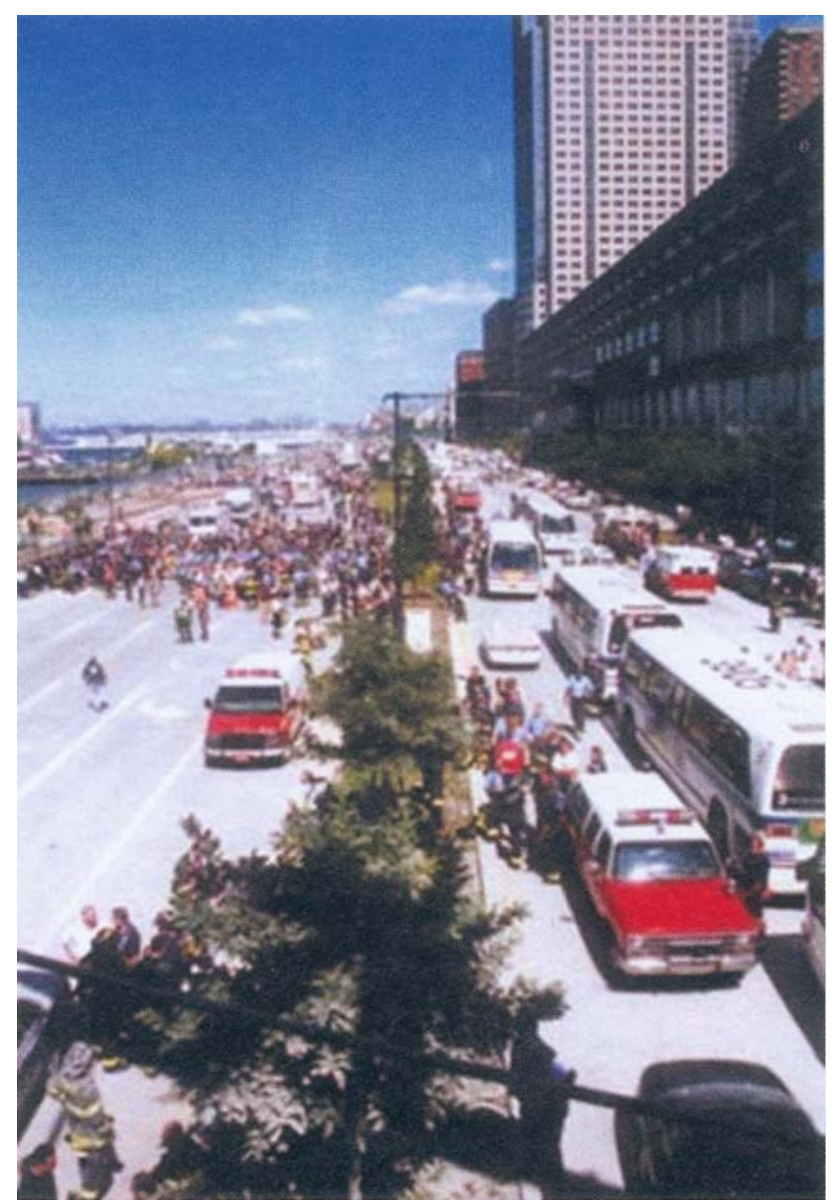

Figure 5. A view of West Street looking north, away from the collapse zone at approximately 10:30 EST on 11 September 2001. Note the congestion of vehicles and personnel making this large multilane highway impossible to use as an access route to the scene.
Personnel, ambulances, and support vehicles. This main artery became incapacitated as an access route, and it took hours to re-organize the ambulance staging area to allow vehicles to get in and out of the scene.

For the majority of the first day, there appeared to be no clearly defined person in charge of the medical operations at the Stuyvesant treatment area. Although EMS incident command was at this location, they were overwhelmed with running the entire disaster operation. A medical command structure was therefore improvised by using "medical rank". Thus the only fully trained trauma surgeon present was placed in charge, followed by three trauma team leaders who were surgery and emergency medicine residents, who were in turn supported by physicians from other specialists, nurses, and medical students. EMTs and paramedics had the primary responsibility of treatment, transport, and supply support. For the early part of the day, the lack of a dedicated EMS officer in charge made communication and coordination extremely difficult. However, by approximately 3:00 p.m., a formal EMS command structure was in place at the Center.

Similar triage areas were set up throughout the city, including at the Ferry Terminal and Broadway and Reade Streets. As the day progressed, large field hospitals were set up at the Chelsea pier and the Jacob Javits center, both large entertainment complexes with wide-open indoor spaces. These facilities did not receive a significant amount of patients. By nightfall the number of patients presenting at these centers was at a minimum and included mostly rescue workers with eye irritation complaints.

\section{Event Evaluation}

The heroism and bravery of the rescuers will forever define the events that occurred on 11 September 2001. However, as with every major disaster, a critical review of the incident is crucial to the maturity of the emergency response to subsequent events. Soon after the recovery operation was completed, the consultant group Mekinsey \& Company was contracted by FDNY to critical assess the operations and to develop recommendations for future preparedness. It is highly recommended that the report he read in detail by anyone involved in organizing a municipality disaster plan [26]. The report identifies difficulties in communication, command operations, and scene control that are applicable to disaster planning on many levels. The highlights of the findings and recommendations are summarized here. 


\section{Communication}

Communication failure, both mechanical and operational, was perhaps the greatest challenge to the disaster response on 11 September. Almost immediately, the fire department had great difficulty keeping track of firefighters on the front line due to failure of the radio system to function within the towers. Typically standard UHF radios will not work in high-rise buildings without a system of repeaters to boost the signal. This left the majority of firefighters and officers unable to communicate with either each other or incident command. This led to a great deal of firefighters not receiving the evacuation order after the first tower collapsed, and may have directly cost lives.

EMS had a similar difficulty with radio operations, although for a different reason. It is standard operational procedure for EMS to have two communication systems broadcasting on the same frequency, one for dispatch-to-unit communication (citywide) and one for incident command. With over 100 ambulances responding, radio traffic became intense and radio operations became crippled. Many EMS units could not receive instructions about where to respond and stage, and therefore responded directly to the scene, exacerbating gridlock around the towers.

Another operational problem was the lack of communication among responding agencies, especially between the fire and police departments. These agencies have a tradition of poor cooperation, and this was highlighted during this particular response. For the majority of the day, the police department established a separate command structure and did not have a representative at the fire incident command post. Obviously, the police department had some very unique challenges of their own, including how to provide "air-cover" and protection against further attacks. Nonetheless, inter-agency communication was cited as a pressing issue for both departments.

Lastly, there was extremely poor communication between incident command, dispatch and receiving hospitals. Some hospitals were quickly over-run without notification, while others made great efforts in resource mobilization without receiving any patients. Dr. Phillip Barrie, Chief of Trauma at Cornell Medical Center recalled, "During this period there was an almost complete lack of information regarding the [situation]... the only communication available was hand-held radios by people on site, which was sporadic and fragmentary... [we did not know] how many patients were coming? When? What were the injuries? As it turns out we were not alone in our concerns" [35].

\section{Command}

FDNY maintains a rigorous command hierarchy that for the most part functioned appropriately during the disaster. Command operations were initially stressed by the size and complexity of the event. However, two situations occurred that virtually incapacitated the command structure; loss of senior leadership, and lack of an effectual command center.

As stated earlier, many of the senior operational officers of the fire department responded directly to the scene, most within the actually towers. Peter Ganci, the chief of the department and the incident commander, was killed when he valiantly and deliberately re-entered the scene to inspect damage caused by the first building collapse [36]. Many other senior leaders were also killed, including civilian leaders such as Deputy Commissioner William Feehan, who had no functional role in the fire operation. The incident command post, which was originally within the South tower, was eventually pulled back to West and Vesey Streets, but was still close enough to be completely destroyed in the first collapse. With a further pull back to Chambers Street, effectual command was not re-established until 11:28 am EST, an hour after the second collapse.

City leadership and senior leaders from multiple agencies had planned for large, citywide disasters and had built a comprehensive, high tech command center to coordinate responses. Unfortunately, this modern command center was on the 28th floor of WTC-7, which was heavily damaged and fully involved in fire after the second collapse. Many city officials even showed up the command center, since there was no provision in the disaster plan for a backup location. Commissioner Van Essen remarked, "How ridiculous, 1 thought [upon arriving at WTC-71. We've got an \$11 million command center and we can't even use it" [37]. Other potential locations for command operations, such as city hall and the police headquarters were evacuated on account of fears that they would be targets for further attacks.

\section{Scene Control}

Attempts to control the scene were hampered by several factors. Responding fire units were instructed to respond to staging areas, such as one at West and Vesey Streets. Ongoing radio communication difficulties caused many units to receive incorrect or no information about where to respond and stage vehicles. Therefore, many units flooded the streets around the WTC complex, to a point where north-bound vehicles were completely blocked [38]. Lack of organization at staging areas also impaired officers' ability to know 
what resources were available and what were already assigned to jobs.

Many units and personnel responded to the scene without direction. Many of these were off-duty firefighters and police officers, or those from areas outside the city such as New Jersey and Westchester. In addition a number of "freelancers", those with training but not a member of any official agency also arrived. This led to confusion in assigning jobs, and eventually made identification of personnel missing after the collapse very difficult. The Mckinsey report goes as far as to say that in the future, personnel responding without direction to scenes such as these should receive "reeducation" and perhaps official sanctions.

After the collapse, thousands of civilians evacuating the area were walking north or out of Manhattan across the Brooklyn Bridge. In addition to the fire, ambulance, and police units that were officially dispatched to the scene, dozens of vehicles and hundreds of personnel from a number of city, state, and federal agencies flooded the area to a point where West Street was completely filled for 30 blocks. This included everything from military vehicles and Red Cross trucks, to animal protection vans, and bottled water delivery trucks handing out free water. Eventually, the police department in conjunction with the US military took security control of the scene, set up barricades and controlled personnel entering the disaster zone.

\section{Summary}

The 2001 World Trade Center disaster was one of the worst terrorist attacks in the recent world history. On account of ongoing world events, we are perhaps now more likely than ever to experience another colossal event such as this. Although on a great scale, difficulties encountered during the response to this event were not unlike those commonly seen in other disasters. Although communication failure was clearly the most distressing problem during this disaster, difficulties with command operations and scene control were also prevalent. Leaders in large municipalities are urged to critically review their response plans in order to preempt difficulties such as these from impeding future responses to large urban disasters.

\section{References}

1. Galveston disaster. Infoplease.com [website]. Available at: http://www.infoplease.com/ipa/Aooo5351.html. Accessed 12/9/ 2002.

2. Naudet J (2002) World Trade Center Disaster.
3. Giuliani RJ. Leadership. New York: Miramax Books, 2002.

4. Personal communication. Gestring, Brian. Forensic Scientist, NYC Medical examiners office. New York, November 2002.

5. Death Certificates for WTC disaster. New York: Office of Vital Statistics, New York City Department of Health, 2002.

6. Anonymous. Rapid assesment of injuries among the survivors of the terrorist attack on the world trade center - New York City, September 2001. Morbid Mortal Wkly Rep (MMWR) 2002; 51:1-5.

7. FDNY Deaths. New York Times online. Available at: http:// www.nytimes.com/library/national/og1101rescuers.html. Accessed 11/22/2002.

8. PAPD Deaths. Available at: http://www.wtcpapdmemorial.com/heroes.htm. Accessed 11/22/2002.

9. NYPD Deaths. Available at: http://www.nyc.gov/html/nypd/ $\mathrm{html} /$ memorial 01.html. Accessed 11/22/2002.

10. Westfeldt A. Terrorist attacks on the World Trade Center cost NYC $\$ 33$ billion to $\$ 36$ billion, experts say. Associated Press 11/ $16 / 2002$.

11. Smith D. Report from ground zero. New York: Penguin Putnam, 2002.

12. Smith D. Report from ground zero. New York: Penguin Putnam, 2002:12.

13. Smith D. Report from ground zero. New York: Penguin Putnam, 2002:24.

14. VanEssen T. Strong of heart. New York: Harper Collins Publishers, 2002.

15. VanEssen T. Strong of heart. New York: Harper Collins Publishers, 2002:19.

16. Smith D. Report from ground zero. New York: Penguin Putnam, 2002:162.

17. Smith D. Report from ground zero. New York: Penguin Putnam, 2002:183.

18. Smith D. Report from ground zero. New York: Penguin Putnam, 2002:28.

19. Glanz J, Lipton E. Towers fell as intense fire beat defenses, report says. New York Times 3/29/2002:A14.

20. Eagar TW, Musso C. Why did the World Trade Center collapse? Science, engineering, and speculation. JOM: J Min Metals Mater Soc 2002; 53(12).

21. NOVA. Why the towers fell. Available at: http://www.pbs.org/ nova/wtc/.

22. Smith D. Report from ground zero. New York: Penguin Putnam, 2002:160.

23. VanEssen T. Strong of heart. New York: Harper Collins Publishers, 2002:54.

24. Company M. Report on the Fire Department response to the World Trade Center disaster [Website]. Available at: http:// www.nyc.gov/html/fdny/html/mck_report/toc.html. Accessed $12 / 9 / 2002$.

25. Mckinsey \& Company. A report on the FDNY response to the World Trade Center Attack. New York, 2002.

26. Mckinsey \& Company. A report on the FDNY response to the World Trade Center Attack. New York, 2002:48.

27. Pryor JP. Personal observations. 9/11/2001.

28. Nierenberg R. Reflections. September 11 - what we learned. Acad Emerg Med 2002;9:217.

29. Menlove S. Reflections. September 11 - what we learned. Acad Emerg Med 2002;9:217.

30. Hirshberg A, Holcomb G, Mattox K. Hospital trauma care in multiple casualty incidents: a critical review. Ann Emerg Med 1996;28:136-44. 
31. Scheibner A. World Trade Center perspective from a Manhattan emergency medicine resident. Ann Emerg Med 2002;39:9-10.

32. Frykberg E, Tepas Jr. Terrorist bombings: lessons learned from Belfast to Beirut. Ann Surg. 1998;208:569-76.

33. Feliciano D, Anderson GJ, Rozycki G. Management of casualties from the bombing at the centennial Olympics. Am J Surg 1998;176:538-42.

34. Mallonee S, Shariat S, Stennies G, Waxweiler R, Hogan D, Jordan F. Physical injuries and fatalities resulting from the Oklahoma City Bombing. JAMA 1996;276:382-7.
35. Barrie P. World Trade Center attack. Paper presented at trauma and critical care. Point/counterpoint XXI syllabus, 2002, Atlantic City, New Jersey.

36. VanEssen T. Strong of heart. New York: Harper Collins Publishers, 2002:34.

37. VanEssen T. Strong of heart. New York: Harper Collins Publishers, 2002:26.

38. Mckinsey \& Company. A report on the FDNY response to the World Trade Center Attack. New York, 2002:29. 
Reproduced with permission of the copyright owner. Further reproduction prohibited without permission. 